ANNOTATED BIBLIOGRAPHY OF CORPORATE FINANCE 


\title{
ANNOTATED BIBLIOGRAPHY OF CORPORATE FINANCE
}

\author{
Compiled by \\ Roger and Eva Lister
}

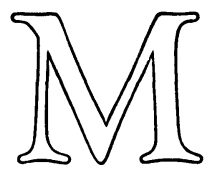


(C) Roger and Eva Lister 1979

Softcover reprint of the hardcover 1st edition 1979 978-0-333-18399-1

All rights reserved. No part of this publication may be reproduced or transmitted, in any form or by any means, without permission.

First published 1979 by

THE MACMILLAN PRESS LTD

London and Basingstoke

Associated companies in Delhi

Dublin Hong Kong Johannesburg Lagos

Melbourne New York Singapore and Tokyo

British Library Cataloguing in Publication Data

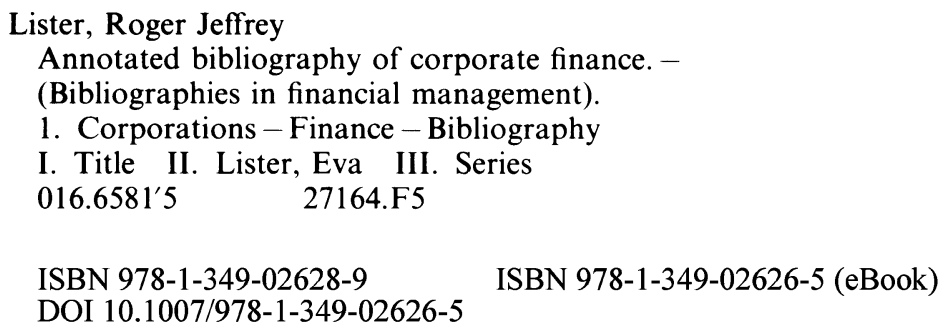

This book is sold subject to the standard conditions of the Net Book Agreement. 


\section{CONTENTS}

Preface vii

$\begin{array}{ll}\text { Acknowledgments } & \text { ix }\end{array}$

Introduction $\quad 1$

List of Periodicals Consulted 5

$\begin{array}{ll}\text { Classification Scheme } & 9\end{array}$

Bibliography 11

$\begin{array}{ll}\text { Author Index } & 179\end{array}$

$\begin{array}{lr}\text { Subject Index } & 237\end{array}$ 


\section{PREFACE}

This classified, annotated bibliography is concerned with the theory and practice of corporate finance. The compilers have set out to include all published works in the English language of lasting interest that are directly relevant to the corporate financing decision.

As a field of study, corporate finance is experiencing an increasingly unitary development at the theoretical level and, to a significant degree also at the practical level. Traditionally isolated areas are now being studied in terms of their unity and interdependence. The restrictive assumptions which beset earlier contributions are being gradually dispensed with. The subject is increasingly studied in the context of its source and related disciplines.

At the practical level, growing theoretical unity has combined with growing technical virtuosity to produce more integrated and comprehensive planning models and positive studies of actual behaviour. For the researcher and the teacher, as well as for the manager, the growing body of normative analyses, positive studies and financial planning models offers a source of valuable instruction and interest.

This bibliography was prompted by the conviction that justice could only be done to the developing scope and intricacy of financial management through a classified, annotated treatment. The aim is to provide a thorough statement of a key area: the corporate financing decision. The compilers believe it to be an area which:

(a) requires rigorous understanding if rational and effective study and decisionmaking is to be carried out;

(b) comprises substantial common ground of a large body of research and practical management decision-taking in finance, accounting, corporate planning and security analysis;

(c) is significant in terms of the magnitude of the managerial decisions entailed.

The compilers hope this work will prove useful to teachers, researchers and students at institutions of higher education, as well as to senior financial managers, accountants, corporạte planners and consultants. It is hoped that librarians will be helped in the service of their readers.

The classification scheme has been selected to facilitate precise location of an area of interest. A brief description is appended to each entry to enable the reader to select the individual works closest to his needs, and to decide whether to seek out the original. The classified bibliography is supported by an alphabetical author index, and a subject index which indicates the main themes of the 1270 works included. 


\section{ACKNOWLEDGMENTS}

We wish to thank the many librarians at universities and other establishments for their courtesy and help in expediting our search. We also thank the respondents to our request for information on forthcoming publications. We are grateful to publishers and to editors of journals for their provision of information, and in particular to the publisher of Journal of business finance and accounting for permission to draw on the synopses of the articles from that journal. We thank Mrs. Hazel Niblock for her skilful composition and preparation of the typescript. 